\title{
NIETZSCHE AND NEO-KANTIAN HISTORIOGRAPHY: POINTS OF CONTACT
}

\author{
Anthony K. Jensen* \\ anthony.jensen@providence.edu
}

RESUMO Nas universidades alemãs do período em que Nietzsche esteve intelectualmente ativo, a tradição kantiana foi amplamente substituida por duas escolas independentes e que, desde então, têm sido rotuladas de "neokantismo". Este artigo apresenta quatro teses principais da filosofia da história neokantiana, mostra como elas são uma decorrência de sua adaptação da tradição kantiana e como Nietzsche se envolve criticamente com os mesmos temas na formação de sua própria teoria histórica. Embora não haja uma influência muito direta entre estas escolas, o contraste com a tradição neokantiana nos permite situar melhor a filosofia da história de Nietzsche em seu contexto apropriado.

Palavras-chave Nietzsche, neokantismo, historiografia, F. A. Lange, $H$. Cohen, W. Windelband, H. Rickert.

ABSTRACT In the German academies of Nietzsche's period of writing, the Kantian tradition was largely displaced in favor of two independent schools that have since been labeled "Neo-Kantianism." This paper presents four key theses about philosophy of history from four Neo-Kantian thinkers, how they follow from their adaptation of the Kantian tradition, and how Nietzsche critically engaged the very same issues in the formation of his own historical theory. Although there is little direct influence between orthodox 
Neo-Kantianism and Nietzsche, their comparison on these points will illuminate their unique adaptations of the Kantian tradition.

Keywords Nietzsche, Neo-Kantianism, Historiography, F. A. Lange, $H$. Cohen, W. Windelband, H. Rickert.

Despite their chronological convergence there has been almost no research into the intersection between Nietzsche and the Neo-Kantians on questions concerning the possibilities and limits of historical judgment. Considered individually, the Neo-Kantians and Nietzsche are among the most-neglected theoreticians of history in the Anglophone world, ${ }^{1}$ occupying an awkward middle-ground between more famous forerunners and successors. Reasons for this are varied, but in no way reflect the philosophical quality of their positions. ${ }^{2}$ Nietzsche seems neither to have had contact with nor any interest in having contact with either the Marburg or Southwest Schools of NeoKantianism, ${ }^{3}$ though the close-knit nature of the German-speaking intellectual world did foster some coincidental associations. ${ }^{4}$ In terms of reconstructing the influence of Nietzsche on the Neo-Kantians or vice versa, ${ }^{5}$ there is almost

1 The evidence for this is of necessity ex silentio. Nietzsche is barely mentioned in important anthologies like Gardiner (1959); Tucker (2009); Budd (2009). He is entirely ignored in many of the field's foundational texts: Collingwood (1946); Popper (1957); Dray (1993); Evans (1997). Neo-Kantianism generally suffers neglect, though it has fared somewhat better with respect to its philosophy of history. It receives a fine discussion in Iggers (1968); Schnädelbach (1984); and Bambach (2009, pp. 477-487). On the other hand, not a single Neo-Kantian thinker is listed among Routledge's "Fifty Key Thinkers on History", edited by HughesWarrington (2008). To my knowledge, there has never been a comprehensive monograph or anthology dedicated to Neo-Kantian philosophy of history. And, also to my knowledge, there has never been so much as a single published paper that attempts to compare Nietzsche and the Neo-Kantians on history.

2 For a summary account of $19^{\text {th }}$ Century Philosophy of History, see sections 4-6 of my "Philosophy of History," Internet Encyclopedia of Philosophy: <http://www.iep.utm.edu/history/>. For a more comprehensive account of the Neo-Kantians generally, see my "Neo-Kantianism," Internet Encyclopedia of Philosophy: <http://www.iep.utm.edu/neo-kant/>. The best analysis of Nietzsche's relationship to NeoKantian epistemology is Bornedal (2010). For alternative descriptions, see also Hill (2003, pp. 13-19); and Green (2002, pp. 36-53).

3 Nietzsche read with some enthusiasm the proto-Neo-Kantians of the 1860's like Liebmann, Fischer, Ueberweg, and of course Lange, whom we will treat in detail. With respect to the two proper schools of Neo-Kantianism, it can only be proven that Nietzsche owned Windelband's "Über den gegenwärtigen Stand der psychologischen Forschung" (1876). He returned it to Felix Schneider's Basel bookstore that same year, and we cannot prove whether he read it. For Nietzsche's reading generally, see Brobjer (2008).

4 First, Lange wrote his dissertation on rhythm and metrics in early Greece under Friedrich Ritschl in 1851. Half a generation later, Ritschl became Nietzsche's mentor and Lange's dissertation topic became a subject of his study. Nietzsche lectured on that same topic repeatedly while a professor at Basel. Second, Eduard Zeller actually wrote to Nietzsche about his philological work on Diogenes Laertius. Zeller to Nietzsche, May 22, 1870; KGB II/2, 211-212. Nietzsche never responded.

5 Of the main schools of Neo-Kantianism, Rickert and Windelband do mention Nietzsche, but the references are minor and desultory. In fact, Windelband actually groups Nietzsche with Julius Bahnsen and Max Stirner as relativist followers of Schopenhauer. Ernst Cassirer, with the advantage of generation worth of critical distance, has insightful things to say about Nietzsche and about his philosophy of history. Many other names are loosely associated with the movement, which never featured a doctrinal orthodoxy in 
nothing to be said beyond what has already been printed about Nietzsche's reception of proto-Neo-Kantian, F.A. Lange. ${ }^{6}$

Nevertheless, Nietzsche and the Neo-Kantians remain paired by more than their shared floruit in the 1870's and 80's and the subsequent neglect of their historical theory. What I aim to present here are the sometimes similar and sometimes contrasting ways Nietzsche and the main schools of Neo-Kantianism adopt Kant's epistemology for their own critiques of historiography and their own programs of what 'proper' historiography should be. For the sake of brevity, I will present only what I take to be the four most salient points of contact between Nietzsche and the Neo-Kantians. In this single paper, my aim is not to exhaust the topic, but to offer a hopeful précis for more detailed research.

\section{Kantian Epistemology and Neo-Kantian History}

What Kant himself said about history is insightful and interesting; but, as anyone who reads it knows, it is hardly 'critical' in Kant's own sense of examining the conditions for the possibility for specifically historical judgment. Like Goethe, Kant's enlightenment faith in the progress of reason and civilization sets the tone in those essays, but scarcely scratches the epistemological problems involved in demonstrating such progress. Hegel, of course, took it as one of his life's tasks to 'prove' the development of history - and needed a dialectical logic Kant would never have recognized in order to do so. ${ }^{7}$ Otto Liebmann's 1865 exhortation to "return to Kant!" expressed the desire a host of thinkers - among them Herman Ludwig von Helmholtz, Eduard Zeller, Friedrich Ueberweg, Kuno Fischer, all of whom Nietzsche read - to temper Hegel's idealism with Kant's critical realism. ${ }^{8}$ All were historical thinkers insofar as they took their intellectual heritage as the necessary starting point of contemporary investigation. In fact, Zeller and Ueberweg remain, even today,

any case. Among those who deal directly with Nietzsche the most overt is Hans Vaihinger, who wrote one of the earliest monographs on Nietzsche, was a founding member of the original 'Stiftung NietzscheArchiv', and referenced him positively throughout his Philosophie des Als-Ob (1911). Georg Simmel, also loosely connected to Neo-Kantianism, wrote what arguably remains the best treatment of Nietzsche and Schopenhauer. See his "Schopenhauer und Nietzsche: Ein vortragszyklus" (1907).

6 The most comprehensive work on the relation between Nietzsche and Lange is the well-known monograph by Stack (1983).

7 Wilhelm Dilthey of course also took a generally Kantian inspiration in his several variegated attempts to ground a specifically historical mode of judgment. Despite their many intersections, however, it is generally agreed that Dilthey does not belong among the Neo-Kantians, hence my mere mention here.

8 Liebmann (1865). 
two of the most meticulous historians of philosophy. But none of them can be said to have attempted to apply Kantian philosophy to historical theory.

In Kant's spirit, if not the letter of his doctrines, Lange's "Die Arbeiterfrage" (1865) and "Die Geschichte des Materialismus" (1866) set the agenda for two transformed Neo-Kantian tendencies. ${ }^{9}$ First, Lange employed the contemporary experimental research into perception and physiology made popular by his teacher and colleague at Bonn, H. L. Helmholtz. Critical philosophy could not remain a purely theoretical discussion of concepts and their relations; its examination of concepts must be grounded in the best empirical research of the natural sciences. ${ }^{10}$ In Lange's day, that meant understanding concepts as relational symbols constructed by the brain for the sake of dealing practically with the welter of sensory experience, ${ }^{11}$ and admitting the status of those symbols as linguistic tokens useful for communication rather than referential designations. ${ }^{12}$ Lange's massive "Geschichte des Materialismus" is a landmark of philosophical history insofar as it exhaustively traces the advances and retreats of various epistemological modes of dealing with reality. But the epistemological mode of dealing with the past (including past modes of dealing with the past) goes rather neglected in Lange's work.

The other displaced Kantian tendency, though rooted in Kant's respectfor-persons doctrine, was the Judeo-socialist revolutionary streak Lange employed to great effect in his "Die Arbeiterfrage". Far removed from both Kant's veneration of constitutional authority and his personal moral conservatism, Lange thought that only direct political representation in a non-stratified social system would guarantee the kinds of rights and social respect Kant envisioned. Lange's theses were strengthened and elaborated by his student and then colleague, Herman Cohen, the widely-considered founder of the Marburg School proper, who in opposition to the Marxist variation of socialism rejected economic and statist nationalism in favor of creative and spiritual

9 Lange's place in Neo-Kantianism is discomfited. On the one hand Cohen is univocally regarded the founder of the Marburg School, despite the fact that Lange preceded and even taught Cohen while at Marburg. On the other hand, Lange's work is in certain ways discontinuous with what Neo-Kantian became in the succeeding generations, despite the fact that Lange took Kant as his philosophical starting point with much the same verve as theirs. In my "Neo-Kantianism," I label Lange a proto-Neo-Kantian to reflect this ambivalent connection.

10 For Lange's admiration of Helmholtz's naturalistic ground of Kant's transcendental aesthetic, see his "Geschichte des Materialismus und Kritik seiner Bedeutung in der Gegenwart" (1902 [1866], II, p. 409).

11 See ibidem, pp. 420-427. That the brain constructs meaningful symbols rather than referential concepts during the act of perception was originally the view of Helmholtz. See, for example, his "Treatise on Physiological Optics", 3 vols., $3^{\text {rd }}$ edition translated by James P. C. Southall (1962 [1867], III, p. 19).

12 Lange (1902 [1866]) II, 384f. Lange's Zeichenstheorie was not taken up explicitly by either Cohen or Natorp, though it reemerged prominently in Hans Vaihingers's Philosophie des Als-Ob (1911) and later in Ernst Cassirer's “Philosophie der symbolischen Formen” (1923-1929). 
development. The Kantian respect for persons doctrine should not be reduced to the stultified Marxist socialism that hawks over equal property rights and material satisfactions at the neglect of aesthetic development, the sensitivity of feelings, and the happiness attainable only by personal achievement. For that, a deeper historical appreciation for the manner one's past shapes one's present was needed. Cohen's posthumous "Die Religion der Vernunft aus den Quellen des Judentums" (1919) maintains religion is not simply an opiate of the masses nor a historical curiosity destined to give way to the forces of rationality, but an entirely intrinsic and necessary aspect of human culture insofar as it cultivates respect for what one's people has lived through, and thereby courage for what is yet to come.

Within the other main division of Neo-Kantianism, alternately labeled the 'Baden' or 'Southwest' Neo-Kantians, Wilhelm Windelband elaborated Helmholtz's methodological distinction between Geisteswissenschaften and Naturwissenschaften into a conceptual distinction in the Kantian style among various kinds of judgments. ${ }^{13}$ At the time, following the remarkable success of the natural sciences in Germany as well as the influence of Comte's positivism, decoupling the methods and aims of science from history was an especially bold move. To abandon scientific method was tantamount to disqualify a field from serious discussion. Nevertheless, Windelband, Rickert, and Dilthey set out to prove the separate but equal worth of these fields through a transcendental examination of the subjective factors that enabled both categories of inquiry. Windelband found that whereas the natural sciences are generalizing, abstracting, law-positing, and aimed at demonstrating necessity, the cultural sciences allow for uniqueness, particularity, and contingency. Cultural sciences are, in other words, 'idiographic' rather than 'nomological', offering descriptions of particular cases intended to inform, rather than universal laws intended to prove. In place of the positivists' hope for scientific deductions, historians deal with events that cannot be isolated, repeated, or tested. They treat particular individuals whose intentions cannot but superficially be subsumed under generalizations, and with human values that resist positivistic nomothetic explanation. "The nomological sciences are concerned with what

13 Although Dilthey is most often credited with the distinction, this is incorrect. H.L.v. Helmholtz's 1862 paper "The Relation of the Natural Sciences to Science in General," is the earliest public discussion that l've been able to find. J.G. Droysen articulates a separation on the basis of the distinction between Verstehen and Erklären in his "Grundriss der Historik" (1868). Dilthey, Rickert, Windelband, and several others as well, discussed and reformulated this distinction for the half-century that followed. I opt not to discuss Dilthey overmuch here since his connection to Neo-Kantianism is tenuous. Dilthey's variation of this division, moreover, varies over the course of his career to the point that it is difficult to employ any one as his final position for the sake of a comparison. 
is invariably the case. The sciences of process are concerned with what once was the case." 14

Windelband's successor at Heidelberg, Heinrich Rickert, more adamantly privileged idiographic judgments over the nomothetic insofar as only the former were capable of addressing the particularity and contingency of human values. Historiography becomes, for Rickert, the exemplary "Geisteswissenschaft" for two reasons. ${ }^{15}$ The first concerns the things studied: the objects of natural science are value-neutral, matters of curiosity or else tools to be put in the service of some other end. Atoms, gravitational forces, and chemical bonds are things about which a natural scientist may develop an interest, of course. But that interest is far removed from what the historian expresses about the Protestant Reformation or the French Revolution or the rise of Bismarck. Moreover, the natural scientist is concerned with atoms or viruses or tulips generally, the historian with this particular human being, with this war, with this economic crisis insofar as he thinks this unique and specific thing is important for life today.

With his concentration on the particular and unique, Rickert followed Windelband in thinking that the traditional scientific reliance on a nomothetic theory of explanation was woefully uncritical and, thereby, inadequate for the cultural sciences. History should instead be understood as a product of a particular and value-driven subject's judgment: "The concrete meaning that is found in the real objects as well as the historiographic principle of selection lies not in the sphere of real being, but in that of value, and it is from here that the connection between the individual value-related method and the meaningful material of historiography must be understood." ${ }^{16}$ Unlike the natural scientist, the historian passes judgment about the successes and failures of policies, assigns titular appellations from Alexander the Great to Ivan the Terrible, decides who is king and who a tyrant, and regards eras as contributions or hindrances to human progress. These judgments follow from their values, both in the sense of assigning which aspects of the past are 'worth' investigation and

14 From Windelband's inaugural address at Strasbourg, entitled "History and natural science." It is reproduced in: "History and Theory" 19 [2] (1980), pp. 165-185, here p. 175. Windelband's hope to ground the distinction between natural and cultural sciences in inherent conceptual kinds, it should be noted lacked both the rigor and the intuitiveness of Kant's deductions. See Bambach (2009, p. 480). Nevertheless Windelband's concern for the conditions of writing history led positively to his innovation about writing the history of philosophy specifically. In place of a chronological series of thinkers and schools and positions, Windelband's history of philosophy concentrates on the major problems of philosophy, how various thinkers take these problems into their own idiosyncratic hands and respond to them in the context of their age.

15 For his most tightly-argued critique of positivist methodology, see Rickert (1962 [1889]).

16 Rickert (1924, p. 70). 
coloring how those aspects are considered. Even if it sacrifices history's status as a science, the values of historians cannot be theoretically excised from what story is told about the past.

Yet neither his opposition to the methods of natural science nor his insistence that historical objects are determined by the values of historians entangled Rickert in the kind of value-relativism so popular among the postmodern disciples of Martin Heidegger, who himself was Rickert's student. On the contrary, Rickert was convinced of the objective character of historical values. Just as for Kant, the intersubjective compulsion of normative judgments rests on the universal character of pure practical reason, so too must values for Rickert be universal in order that historical judgment compel assent intersubjectively. "The fact that cultural values are universal in this sense is what keeps concept formation in the historical sciences from being altogether arbitrary and thus constitutes the primary basis of its 'objectivity'. What is historically essential must be important not only for this or that particular historian, but for all." 17 Thus, although the historian's values do indeed inform their account, those values express proximate universals across culture and eras. Individual prejudice and bias may seep in to an historical account, but only to the extent that the historian lacks the necessary feeling for these universal human values.

To recapitulate the salient points of these four Neo-Kantian thinkers ${ }^{18}$ for the sake of our comparison:

1. (Lange) The writing of history must acknowledge the epistemological factors that constitute judgment. This involves a more physiological-naturalistic deduction than Kant's transcendental one. Historical judgment, like judgment generally, consists in symbolic rather than referential descriptions.

2. (Windelband) History involves fundamentally different standards of judgment than the natural sciences. Accordingly, Geisteswissenschaften ought not try to emulate Naturwissenschaften with respects to aims, methods, or standards of success.

3. (Cohen) The value of historiography is primarily cultural and formative. The history of Jewish culture in particular teaches us a great deal that can stand as a bulwark to the statist materialism of the Marxists.

4. (Rickert) (A) Judgments about historical objects are necessarily informed by a particular historian's values. (B) The values that inform historical judgment are universal. Consequently the writing of history remains objective and valid for all.

17 Rickert (1962 [1889], p. 97). Both passages from Rickert are cited in Bambach (2009, p. 482).

18 It should be noted that I do not say "Neo-Kantian" views. The reason concerns the character of NeoKantianism as a movement. While the participants share a common respect for the Kantian tradition, there is little in the way of 'orthodox' beliefs or attitudes, either between the two main schools or even among the members of the individual schools themselves. The four points here represent the thoughts of four philosophers, and it would be quite wrong to assume they would all have agreed to one another's position. 


\section{Similarities and Differences with Nietzsche}

Nietzsche raised and formed his own views on each of these themes. In fact, these four theses are among the most important for Nietzsche. Although he and the Neo-Kantians have a common remote ancestor in Kant, and a common proximate one in Lange, neither can be thought to have been substantially influenced by the other. Nevertheless, Nietzsche generally agrees with Lange's epistemological remark (1) and extends this to the writing of history. Windelband's distinction between Geistes- and Naturwissenschaften (2) would be accepted by Nietzsche insofar as one's model of natural science is exhausted by the positivistic. For Nietzsche, however, it is not. Nietzsche leaves room for a kind of science that would be consistent with historiography. Cohen's Jewish history (3), which on the surface seems wholly antithetical to Nietzsche's critiques of spirituality generally, and of Jewish spirituality specifically, is something with which Nietzsche would have had a limited but definite sympathy. Nietzsche would have agreed with Rickert's position (4a) on the constitutive nature of values in history, but both anticipated and rejected his claim (4b) about the universality of historical values. Each of these points deserves considerably more analysis than I can offer here; and so in what follows, I present only summaries of Nietzsche's positions on these Neo-Kantian theses. ${ }^{19}$

In the case of the first point, Nietzsche's own view of epistemology, especially in his earlier years, has been shown to have been foundationally influenced by Lange. ${ }^{20}$ In his 1873, "On Truth and Lies in an Extramoral Sense", composed in the same notebook (U II 2, according to the numbering of archivist Hans Joachim Mette) that contains the first draft of "On the Uses and Disadvantages of History for Life" (published in January 1874), Nietzsche adopts both Lange's notion of concept formation as an aesthetic symbolization that renders general what is unique in experience for the sake of the practical success of the human species and also Lange's critique of truth as correspondence between words and things. Philosophical investigation must begin with epistemological reflection, but it cannot start with a purely theoretical transcendental deduction of the conditions of the possibility of

19 For a much more thorough treatment of at least Nietzsche on this topic, see my "Nietzsche's Philosophy of History" (2013). On his relation to early Neo-Kantianism, see my "Helmholtz, Lange and the Unconscious Symbols of the Self" (2013).

20 Besides Lange, there are a fairly large number of authors who influenced Nietzsche's early epistemology, most prominent among them Afrikan Spir, Gustav Gerber, Helmholtz, Teichmüller, and obviously Schopenhauer, each of whom, it might be noted, saw their work as an expansion and correction of Kant. The best summary statement of these influences is Small (2001). 
experience. It must go further back to the naturalistic conditions that evolved in the material brain, that which simultaneously enables judgment and precludes the possibility of naïve empirical realism.

Lange did not apply his naturalistic deduction to the realm of history, however great his own contribution to Ideensgeschichte. But Nietzsche certainly expanded Lange's critique of naïve empirical realism and Zeichenbegriffe to his own historiography. "Just as we understand characters only imprecisely, so do we also understand facts: we speak of identical characters [gleichen Charakteren], identical facts [gleichen Facten]: neither exists." 21 Thus to speak of tyrants and heroes, of wars and cultural achievements is, as Lange held, to utilize general words for things that are entirely unique and particular. No two designations of kings have the exact same predicate extensions, nor do any two battles: identifying them with a single word is, strictly speaking, false: an identification of two things that are not identical. ${ }^{22}$ This hardly means that historiography either suffers a unique problem (designations generally incur this objection) or that historians should cease doing what they do and designate things correctly. It should, however, admit that the status of its descriptive designations cannot be that of referential denotation of real objects. What historiography does, Nietzsche thinks, is not describe historical objects as they really were - that is something impossible for anyone, including historians -, so much as communicate meanings for all sorts of contemporary purposes by means of language considered as symbols. ${ }^{23}$

\begin{abstract}
A historiographer [Geschichtsschreiber] has to do, not with what actually happened, but only with events supposed to have happened: [...] - a continual generation and pregnancy of phantoms over the impenetrable mist of unfathomable reality. All historians [Historiker] speak of things which have never existed except in representation [Vorstellung]. ${ }^{24}$
\end{abstract}

21 MaM II, WS 11; KSA 2, 546. See also WL 1; KSA 1, 880. All references to Nietzsche accord the standard Siglen of the "KSA: Sämtliche Werke: Kritische Studienausgabe", 15 vols., edited by Giorgio Colli and Mazzino Montinari (1988). All references to Nietzsche's correspondence accord "KSB: Sämtliche Briefe: Kritische Studienausgabe", 8 vols., edited by Giorgio Colli and Mazzino Montinari (1986). Translations throughout are my own.

22 There is an obvious tension between Nietzsche's critique of historical judgment and his own history whenever he discusses slaves, Jews, Greeks, artists, etc., especially with an eye toward explaining psychologically why these types act as they do. In a recent monograph, I argue that Nietzsche is not actually inconsistent here, but seeks to employ terms as anti-realist symbols intended to convince rather than referential designations intended to prove. See my "Nietzsche's Philosophy of History", Chapter 5.

23 See, for but one example, NF June - July 1885, 38[14]; KSA 11, 614.

24 M 307; KSA 3, 224f. 
The causal links between two alleged historical 'objects' or 'events' is a key case in point. To say that a riot was caused by a speech, that poverty resulted from bad fiscal policy, that a king married in order to solidify an alliance, that an empire fell because of decadence or that a war was fought for an ideal - all statements like these, the very stock and trade of historiography, make three clear mistakes stemming from a naïvely realist epistemology that Nietzsche and Lange both reject. First, realist historiographers identify loosely connected phenomena under single names so that they can be inserted in an alleged causal relationship. Second, they attribute causal relationships where none can be experienced directly and thereby confirmed or disconfirmed. Third, they presume both of these mind-generated representations as referring to a reality independent of the mind. Only symbolic representations can be cognized. Causality, too, is not 'in' the things-themselves, but a useful fiction ascribed by the human mind to make manageable the otherwise inscrutable associations among the phenomena under investigation.

[O]ne should use 'cause' and 'effect' only as pure concepts [Begriffe], which is to say, as conventional fictions for the purpose of description and communication, but not explanation [Erklärung]. For the 'in-itself' there is nothing at all like 'causal association', 'necessity', or 'psychological un-freedom', since the 'effect' does not follow 'from the cause', no 'law' rules over it. ${ }^{25}$

One ought not conclude that historiography should hereby cease to exist, for Nietzsche, but that a certain modesty should be involved in recognizing the essentially subjective element in "Geschichtsschreibung": that the human mind, and all the minds of all the historians accordingly, cannot reach either objects or their associations 'in-themselves', but can prescribe meaningful symbols for communicating various intentions. If this true of human thought generally, then it follows for thought about history specifically.

The next point of contact with Neo-Kantian philosophy of history concerns Windelband's claim (2) that not only the methods but also the standards of judgment within historiography are irresolvably different than that of natural science insofar as the latter deals with nomothetic deductions and the former with idiographic descriptions. Nietzsche shares with Windelband the critique of methodological identity of the sciences purported by positivism. History, for both, is valuable and instructive despite its inability to prove or demonstrate by means of logical deduction from universal laws. Part of the reason for this involves Nietzsche's adoption of Lange's critical realism. Another 
part involves an argument closer to Windelband's nomothetic-idiographic distinction: history should treat particularity as particularity, rather than regard particulars as mere instances of universals from which to deduce historical 'necessities'.

What inconsistency is there after all between the activities of man and the course
of events? I am particularly struck by the fact that historians [...] cease to instruct
as soon as they begin to generalize, betraying in their obscurity the sense of their
weakness. In other disciplines, generalizations are the crucial factor since they
contain the laws. But if such assertions as that cited are meant to be valid laws, then
we could reply that the historian's work is wasted. For whatever truth is left in such
statements, after subtracting that mysterious and irreducible residue we mentioned
earlier, is obvious and even trivial since it is self-evident to anyone with the slightest
range of experience. ${ }^{26}$

That the logical compulsion of both the natural and cultural sciences resides in its capacity for nomothetic deduction is a view held by positivist historical theorists from Comte to Buckle to Hempel. But whereas Windelband rarely doubted whether natural science was exhausted by a combination of materialist ontology and positivist logic, there is a complex ambivalence in Nietzsche's attitude about science. On the one hand, Nietzsche considers naïve those same materialist scientists who fancy themselves to provide dogmatic truth about some 'real' world, and finds obtuse those same positivists who believed they could somehow articulate those objects with a subject-free objectivity. ${ }^{27}$ On the other hand, some scientists - especially among the physiologists and critico-empiricists - offered models that Nietzsche not only tolerated but admired. ${ }^{28}$ Nietzsche's own ideal of science required the recognition of its basis in the subjective facticities of its practitioners, a naturalistic attitude, an experimentalist's aversion to dogmatism, and a 'healthy' orientation to life. ${ }^{29}$

Nietzsche held a similar attitude with respect to history and historians. As in the passage above, historiographers searching for laws that unlock the mysteries of becoming - a common trait among Hegelians and positivists alike - embrace an untenable model of explanation insofar as their deductions

26 HL 6, KSA 1, 291ff. See also FW 335; KSA 3, $562 \mathrm{ff}$.

27 The full expression of this view can be found in the third essay of Nietzsche's "On the Genealogy of Morals".

28 Among these are the proto-Neo-Kantians mentioned earlier as well as contemporary physiologists and biologists, especially Johannes Müller, Emil du Bois-Reymond, Wilhelm Roux, and William Rolph. For a treatment, see Brobjer and Moore (2004). Nietzsche also thought highly of the critico-empiricists, especially Ernst Mach and Richard Avenarius, with whom he even corresponded. An insightful examination of Nietzsche within this tradition is Hussain (2004, p. 326-368).

29 Nietzsche's philosophy of science is hotly debated at the moment. Among a number of other books and articles, see especially Heit \& Heller (2013); and Heit et al. (2012). 
rely upon identities that simply don't exist. The same goes for historians who seek to emulate the 'objectivity' of the natural sciences, principal among them the Berlin Historical Schools representatives: Ranke, Savigny, Droysen, as well as Henry Thomas Buckle and Richard Bentley, in England. "Those who say, 'But certainly classical culture survives as an object of pure scholarship, even if all its educational aims are disavowed,' deserve this reply: 'Where is pure scholarship here? Achievements and qualities have to be assessed, and the assessor has to stand above what he assesses." "30 The point is not that historiography is futile. ${ }^{31}$ Reflective of its epistemic limits, it should regard itself as a selective prescription of useful ways of communicating meaning, the kind that express the only sometimes-conscious values of an historian and which has great power in transforming individuals and cultures. "The objectivity of historians is nonsense." "[I]t can and should never become a pure science," - at least in the sense that Ranke, Buckle, or Comte envisioned.

Bad science and bad history, for Nietzsche, bear the same sins: when objectivity is taken to mean selflessness, when descriptions are regarded as referential rather than symbolic, and when their practitioners stand smugly convinced that their explanations are universal, necessary, and without possible revision - here science and historiography both are at their worst. On the other hand, the spirit of good science looks very much like that of good history: an acknowledgment of the subjective factors that color their judgments about the world, a recognition that descriptions can never be thought to really map onto the world, and a modesty about the universality and necessity of one's explanations. Nietzsche agrees with Windelband, then, insofar as he thinks history properly practiced cannot be subsumed by the methods or standards of positive natural science; but insofar as he denies that positivism exhausts the possibilities of either science or history, his distinction between them does not amount to an unbridgeable opposition.

The issue of objectivity brings us to Cohen's contention (3) that historiography should be marshaled for its transformative powers in enlivening a people and for resisting the anti-cultural statists who have used historiography as a tool to advance a nationalist power-grab masquerading as social compassion. To say that Nietzsche did not advocate a specifically Jewishspiritual rebirth of culture is only too obvious. ${ }^{32}$ But it is equally obvious that

30 NF beginning of 1875-spring 1876, 5[53]; KSA 8, 54ff. See all the rather comical chart of the characteristics of bad philologists at NF spring-summer 1875, 5[59]; KSA 8, 57.

31 A view attributed to Nietzsche by, for examples, Gossman (2000, p. 434); and White (1978, p. 32).

32 Without delving too deeply into the topic, Nietzsche holds a quite nuanced and ambivalent view of Judaism. On the one hand, he praises Judaism for its cultural resistance to hostile external forces. On the other, he excoriates the strategies they used for that resistance as being hostile to life. 
he considered the proper attitude toward history a necessary condition for a people's cultural health. He writes, "The question of the degree to which life requires the service of history at all, however, is one of the supreme questions and concerns in regard to the health of a man, a people or a culture." ${ }^{33}$ Looked at as a mere collection of dates and places, history, for both Nietzsche and Cohen, has almost no cultural value. Practiced properly, history for both is an essential tool for life affirmation.

There are three primary historical attitudes Nietzsche lists in his 1874 "Nutzen und Nachtheile": the monumental, the antiquarian, and the critical. None of them is an 'objective' writer of history. Each of these types bring to the past their own desires, values, and drives. "Thus man spins his web over the past and subdues it, thus he gives expression to his artistic drive - but not to his drive towards truth or justice. Objectivity and justice have nothing to do with one another." 34 The monumental historian reflexively highlights 'great' events and figures, and holds them up as exemplars for what greatness can be achieved today; he runs the risk, however, of distorting the often-ignoble processes by which those events came about. The antiquarian historian does definite service to life insofar as he seeks to preserve and revere the otherwise forgotten aspects of the past; but by always looking backwards, away from present-day concerns, he can also 'mummify' life. The critical historian turns her eye against any tradition to call into question the historical foundations of our long-held values; yet, for her service to life in clearing away the old for the sake of the new, the critical historian can disavow too much, to the point that even a society's healthiest values are devalued. For all three types, whether they use history 'well' is not a matter of whether they 'get their facts straight', but of the degree to which their activity serves life or hinders it.

Cohen's own historical reflections tell the story of the struggles and overcomings of his Jewish people. As such Cohen is no objective historical scientist either, never dealing critically with sources like the philologist, never trying to prove or predict like Buckle or Comte, never trying to scruple out the metaphysical riddle behind the "Weltprozess" like Hegel or Marx. Although coldly calculating in his logic and epistemology, from his writings on Judaism spring alternating spells of hope, lament, and pride. To be sure, his history is selective. It speaks of the 'important' and 'formative' moments of Jewish traditions, and such moments are not valuable in and of themselves. They 
acquire value only insofar as there are historians and audiences who value them in the present. Cohen looks to the past insofar and indeed only insofar as it more deeply roots his conviction of his people's indispensable value over history. And he thinks that by doing so, he will help his contemporaries to develop a healthy respect for their past, to take courage that knowledge of what one has gone through can gird his people for what is to come. In this way, Cohen's historical reflections on Judaism, selective and value-driven as they are, coincide with Nietzsche's vision of the healthy 'antiquarian' historian, he who "preserves and reveres - to him who looks back to whence he has come, to where he came into being, with love and loyalty; with this piety he, as it were, gives thanks for his existence. By tending with care that which has existed from old, he wants to preserve for those who shall come into existence after him the conditions under which he himself came into existence-and thus he serves life." 35

Nietzsche's investigation into what 'drives' an historian to represent history in the particular way he or she does leads to a natural comparison with Heinrich Rickert's conviction (4a) that values inform an historian's account of the past. Nietzsche's early tripartite division between kinds of historians and his later, more fully developed theory of perspectivism both hold that values color an historian's judgment. When we wonder why history unfolds as it does, our queries are not pure, speculative attempts to uncover facts. Our inquiries are value-driven. Their resolutions need not demonstrate anything logically, but must satisfy the drives that generated the initial curiosity. "We are not looking for just any type of explanatory cause, we are looking for a chosen, preferred type of explanation, one that will most quickly and reliably get rid of the feeling of unfamiliarity and novelty. [...] The banker thinks immediately of his 'businesses', the Christian of 'sin', the girl of her love." ${ }^{36}$

However, where Rickert remains Kantian in his conviction that values stem from rational decisions to hold certain goods, Nietzsche's psychology investigates more deeply into the unconscious drives, desires, and instincts, of which values are only a sort of conscious façade. A historian cannot set out

35 HL 3; KSA 1, 265.

36 GD Errors 5, KSA 6, 93. While Nietzsche is speaking of explanation generally here, the application to historical explanation follows consistently. The point here is not just that the banker, Christian, girl, are naively relying on a folk psychology. They are, but the wider point is that explanations are held to be true for a-logical reasons such as familiarity, being accustomed, and dispelling the feeling of uncertainty. There have been a number of quite fine interpretations of Nietzsche's critique of motivation and explanation, especially when it comes to autonomous action. See especially the collection of papers by Gemes and May (2009). For my own work on historical explanation in Nietzsche specifically, see my "Nietzsche's Philosophy of History", Chapter 5. 
with a rational commitment to 'choose' to be a critical or antiquarian historian, any more than a knower can choose to represent the world spatio-temporally or the eye can choose the frequency of light it processes. For Nietzsche, "[o] ur most sacred convictions, unchangeable in regard to our supreme values, are judgments of our muscles." 37

Due to his concentration on the multifarious psychological attitudes toward history, Nietzsche would have denied quite fervently Rickert's faith in a universal set of values that drive historians (4b). The fact that there are three distinct types who are driven to represent the past in determinate ways, and many more perspectives that will drive any number of agents to discern the world in any number of ways, means that there can be no absolutely privileged set of values that would drive the 'objective' historiography Rickert seeks. There are no universally-sought-for explanations that could be thought to have derived from 'rational' values, that is, universally accepted values. In fact, objectivity for Nietzsche is precisely the opposite of a single way of valuing or explaining: "the more eyes, different eyes we learn to set upon the same object, the more complete will be our 'concept' of this thing, the more 'objective'." 38 While there is no objectivity in either the positivist 'subjectfree' sense or in Rickert's 'universal values' sense, Nietzsche acknowledges that those sets of values that garner a wide assent in a given community are themselves labeled that community's 'objective' values.

Human beings judge not merely through the filter of Kantian categories, nor through some universal set of values. Human judgment is a function of a deeply psychological affectivity, one that is in large part due to the historical development of a person, of a culture, and of a species over time. Like Dilthey, and later, Cassirer, who both objected to Rickert on this point, too, Nietzsche thinks a psychology of the values of historians would provide a more responsible lens through which to view the writing of history. ${ }^{39}$ But unlike Dilthey and Cassirer, Nietzsche thinks this will not be grasped through an act of historical Verstehen - a sensitive understanding of the hermeneutics of historical representation - but through recognizing the various competing power-drives among the various historians. Although Nietzsche is not responding directly to Rickert or any other Neo-Kantian, he is in diametrical opposition to the entire tradition when he writes quite early in his career,

39 To be specific, Dilthey thought that various sets of values could be grouped together in the language of Weltanschauungen, though it remains problematic how he thought either they could so be grouped without superficiality or else how his grouping avoided the problem of value-relativism. 
"What is history other than an unending struggle of different and countless interests for their existence?"40

\section{Conclusion}

In this short paper I have not provided an exhaustive account of any of these thinkers or of their relationships to one another. Because the connection between the Neo-Kantians and Nietzsche has remained largely underreported, my hope is that drawing attention to four salient points of contact between them will generate more detailed discussion. Because they both take the Kantian epistemological program as their basic starting point, because they both recognize a number of problems that result from the basic Kantian standpoint, because they each demonstrably adapt aspects of that standpoint to fit their own views of history, and because they each target as rivals the positivists and materialists, their further comparison and contrast will be particularly helpful in understanding them individually and in connection.

\section{Bibliography}

BAMBACH, C. "Neo-Kantianism." In: A. Tucker (ed.). A Companion to the Philosophy of History and Historiography. West Sussex: Wiley-Blackwell, 2009. pp. 477-487.

BORNEDAL, P. "Surface and the Abyss: Nietzsche as Philosopher of Mind and Knowledge". Berlin: Walter de Gruyter, 2010.

BROBJER, T. H. "Nietzsche's Philosophical Context". Urbana: University of Illinois Press, 2008.

BROBJER, T.; MOORE, G. (ed.). "Nietzsche and Science". Aldershot: Ashgate Publishing, 2004.

BUDD, A. (ed.). "The Modern Historiography Reader". New York: Routledge, 2009. CASSIRER, E. "Philosophie der symbolischen Formen". Berlin: Bruno Cassirer, 1923-1929.

COLLINGWOOD, R. G. "The Idea of History". Oxford: Oxford University Press, 1946.

DRAY, W. "Philosophy of History". 2 ${ }^{\text {nd }}$ ed. Upper Saddle River, NJ: Prentice Hall, 1993.

EVANS, R. "In Defense of History". New York: Norton \& Co., 1997.

HUGHES-WARRINGTON, M. (ed.). "Fifty Key Thinkers on History". London/New York: Routledge, 2008. 
GARDINER, P. (ed.). "The Philosophy of History". London: Oxford University Press, 1959.

GEMES, K.; MAY, S. (ed.). "Nietzsche on Freedom and Autonomy". Oxford: Oxford University Press, 2009.

GOSSMAN, L. "Basel in the Age of Burckhardt: A Study in Unseasonable Ideas". Chicago: University of Chicago Press, 2000.

GREEN, M. S. "Nietzsche and the Transcendental Tradition". Urbana, IL: University of Illinois Press, 2002.

HEIT, A. et al. "Nietzsches Wissenschaftsphilosophie". Berlin: Walter de Gruyter Press, 2012.

HEIT, H.; HELLER, L. (ed.). "Nietzsche im 19. Jahrhundert. Natur-, geistes-, und sozialwissenschaftliche Kontexte". Berlin: Walter de Gruyter Press, 2013.

HELMHOLTZ, H. (1867) “Treatise on Physiological Optics”. $3^{\text {rd }}$ edition translated by James P.C. Southall. New York: Dover Publications, 1962. 3 vols.

HILL, R. K. "Nietzsche's Critiques: The Kantian Foundations of his Thought". Oxford: Oxford University Press, 2003.

HUSSAIN, N. "Nietzsche's Positivism." European Journal of Philosophy, 12 [3], 2004, pp. 326-368.

IGGERS, G. "The German Conception of History". Middletown Ct: Wesleyan University Press, 1968.

JENSEN, A. K. "Helmholtz, Lange and the Unconscious Symbols of the Self." In: J. Constancio (ed.). Nietzsche and the Problem of Subjectivity. Berlin: Walter de Gruyter Press, 2013.

JENSEN, A. K. "Nietzsche's Philosophy of History". Cambridge: Cambridge University Press, 2013.

LANGE, F. A. (1866). "Geschichte des Materialismus und Kritik seiner Bedeutung in der Gegenwart”. Iserlohn: J. Baedeker, 1902.

LIEBMANN, O. "Kant und die Epigonen". Stuttgart: Carl Schober, 1865.

NIETZSCHE, F. "KSA: Sämtliche Werke: Kritische Studienausgabe". Edited by Giorgio Colli and Mazzino Montinari. Berlin: Walter de Gruyter, 1988. 15 vols.

NIETZSCHE, F. "KSB: Sämtliche Briefe: Kritische Studienausgabe." Edited by Giorgio Colli and Mazzino Montinari. Berlin: Walter de Gruyter, 1986. 8 vols. POPPER, K. "The Poverty of Historicism". London: Routledge \& Kegan, 1957. RICKERT, H. (1889). "Science and History: Critique of Positivist Epistemology". New York: Van Nostrand, 1962.

RICKERT, H. "Die Probleme der Geschichtsphilosophie". Heidelberg: Winter, 1924. SCHNÄDELBACH, H. “Geschichtsphilosophie nach Hegel”. Freiburg: Alber, 1984. SIMMEL, G. "Schopenhauer und Nietzsche: Ein vortragszyklus". Leipzig: Duncker und Humblot, 1907.

SMALL, R. "Nietzsche in Context". Aldershot/Burlington: Ashgate, 2001.

STACK, G. J. "Lange and Nietzsche". Berlin/New York: De Gruyter, 1983. 
TUCKER, A. (ed.). "A Companion to the Philosophy of History and Historiography". West Sussex: Wiley-Blackwell, 2009.

WHITE, H. "Tropics of Discourse: Essays in Cultural Criticism". Baltimore: Johns Hopkins University Press, 1978.

WINDELBAND, W. "Über den gegenwärtigen Stand der psychologischen Forschung”. Leipzig: Breitkopf \& Härtel, 1876. 